\title{
DNA repair and mutagen sensitivityof epithelial cells and lymphocytes in oropharyngeal cancer
}

\author{
MAXIMILIAN REITER ${ }^{1}$, PHILIPP BAUMEISTER ${ }^{1}$, SONJA JAISER ${ }^{1}$, ANDREAS REISS $^{1}$, \\ SABINA SCHWENK-ZIEGER ${ }^{1}$, NORBERT KLEINSASSER ${ }^{2}$ and ULRICH HARRÉUS ${ }^{3}$
}

\author{
${ }^{1}$ Department of Otorhinolaryngology and Head and Neck Surgery, Ludwig Maximilians University, D-81377 Munich; \\ ${ }^{2}$ Department of Otorhinolaryngology and Head and Neck Surgery, Julius Maximilians University, D-97080 Wuerzburg; \\ ${ }^{3}$ Department of Otolaryngology and Head and Neck Surgery, Friedrich Alexander University, D-91054 Erlangen, Germany
}

Received April 21, 2011; Accepted August 24, 2011

DOI: $10.3892 / \mathrm{ol} .2011 .417$

\begin{abstract}
Tobacco-associated nitrosamines are known carcinogens causing DNA damage in epithelial cells of the head and neck. A matched case-control study was performed to evaluate the sensitivity of patients with squamous cell cancer (SCC) of the oropharynx, and controls to tobaccoassociated nitrosamines. Quantitative DNA repair was evaluated following a period of 15 and $30 \mathrm{~min}$. Fresh biopsies from 100 male donors of macroscopically healthy oropharyngeal cells and lymphocytes (50 SCC patients and 50 controls) were incubated with $\mathrm{N}$-nitrosodiethylamine (NDEA), 4-(methylnitrosamino)-1-(3-pyridyl)-1-butanone (NNK) or $\mathrm{N}$-nitrosonornicotine (NNN). DNA damage in epithelial cells and lymphocytes was assessed using the comet assay. Following incubation with NDEA, cells underwent a period of DNA repair. All of the nitrosamines caused equivalent genotoxic damage in mucosal cells and lymphocytes of the two groups. Lymphocyte DNA repair capacity in the control group (26.8 and $37.1 \%$ after 15 and $30 \mathrm{~min}$ ) was comparable to the tumor group (23.6 and 40.6\%). However, epithelial cell DNA repair capacity of carcinoma patients was significantly reduced to $17.1 \%(15 \mathrm{~min})$ and $23 \%$ (30 $\mathrm{min})$ compared to the DNA repair of the control group $(36.2 \%, 15 \mathrm{~min}$ and $46.0 \%$, $30 \mathrm{~min})$. Mutagen sensitivity was comparable in patients and controls. Thus, reduced epithelial cell DNA repair capacity of tumor patients is a possible endogenous risk factor for the development of head and neck squamous cell cancer.
\end{abstract}

\section{Introduction}

The incidence and mortality of upper aerodigestive tract carcinomas remain persistently high regardless of diagnostic and

Correspondence to: Dr Maximilian Reiter, Department of Otorhinolaryngology and Head and Neck Surgery, Grosshadern Clinic, Ludwig Maximilians University, Marchionini Street 15, D-81377 Munich, Germany

E-mail: maximilian.reiter@med.uni-muenchen.de

Key words: mutagen sensitivity, DNA repair, lymphocytes, oropharynx, comet assay, repair capacity therapeutic improvements (1). Exogenous risk factors, such as tobacco smoke and alcohol consumption, are acknowledged causes of head and neck cancer (2). However, only a fraction of smokers are likely to develop head and neck cancer during their lifetime. Therefore, the importance of endogenous risk factors is of growing interest in the multifactorial genesis of head and neck squamous cell cancer (HNSCC). Individual mutagen sensitivity and DNA repair capacity are likely to be candidates affecting an individual's susceptibility to cancer (3).

Tobacco-associated nitrosamines, such as N-nitrosonor-nicotine (NNN), 4-(methylnitrosamino)-1-(3-pyridyl)1-butanone (NNK) and N-nitrosodiethylamine (NDEA) are known to be involved in the carcinogenesis of HNSCC. NNN is classified as a class 1 carcinogen by the IARC (4). This nicotine derivative is found in tobacco smoke, with 200-3000 ng in cigarettes without filters (5). NNK is classified as class 1 by the IARC as well, although it was found to be a stronger carcinogen in animal testing $(4,6)$. NDEA is a class $2 \mathrm{~b}$ carcinogen, and its effect is local and systemic, with 20-70 ng in the smoke of cigarettes without filters $(5,7)$. The nitrosamines are metabolized in the cells by cytochrome P-450-dependent hydroxylases into an alkylating agent, which may induce DNA strand breaks and cause incomplete base excision repair. Furthermore, NNN and NNK have genotoxic effects through the formation of oxygen radicals (8).

As in most tumors, the regulatory steps are altered during multi-step tumor development (9). Regular cell survival is dependent on a well-balanced relationship between ongoing DNA damage and repair $(10,11)$. The importance of DNA repair capacity (DRC) on cancer susceptibility was previously described in lung cancer patients (12). The ability to detect and repair DNA damage caused by environmental toxicants or endogenous processes is assumed to be a significant defense mechanism against the development of head and neck cancer.

Most studies on DRC are based on lymphocytes as the surrogate cell type $(13,14)$. However, environmental carcinogens primarily damage the mucosa of the upper aerodigestive tract, with epithelial cells being the first target for head and neck carcinogenesis. Due to previous findings showing poor correlation between genotoxic sensitivity of peripheral blood 
lymphocytes and upper aerodigestive tract epithelia, we included the two cell types in our investigations to further differentiate systemic and local effects (15).

The aim of the study was to evaluate mutagen sensitivity and DRC in human lymphocytes and epithelial cells of the oropharynx of patients with and without squamous cell carcinoma (SCC) of the oropharynx. DNA fragmentation following nitrosamine-induced damage, as well as DNA repair capacities in 15 and $30 \mathrm{~min}$, were measured using the alkaline single cell microgel electrophoresis (comet) assay. DRC following nitrosamine-induced DNA damage was presented within matched patient groups using parameters such as age, gender, tobacco and alcohol consumption.

\section{Materials and methods}

Biopsies and blood samples. Macroscopically healthy epithelial biopsies were obtained from oropharyngeal resection specimens of SCC patients and from surgery of the oropharynx in patients without SCC. For the evaluation of DNA damage and repair using nitrosamines, SCC patients $(n=50$, all male, mean age 51.3 years; range $35-62)$ were matched to control patients $(n=50$, all male, average age 50.4 years; range 35-62). Only mucosa that had to be resected for surgical reasons were used to avoid additional stress for the patients. Subjects were informed about the experiments and had signed a written consent statement. Tumor patients were first-time cancer patients and did not receive any prior treatment, including radiotherapy or chemotherapy. Control patients underwent tonsillectomy based on the diagnosis of tonsillitis or obstructive sleep apnea syndrome (OSAS). Lymphocytes were isolated by centrifugation of $20 \mathrm{ml}$ heparinized peripheral blood, which was drawn prior to treatment. Patients included in the study were matched by gender, age, alcohol and tobacco consumption. All of the subjects were consumers of alcohol and tobacco smoke. Patient data are shown in Tables I (controls) and II (patients with SCC). The study was approved by the Ethics Commission of the Medical Department, Ludwig-Maximilians-University Munich (No. 221/04).

Cell separation. The mucosa samples underwent enzymatic digestion using collagenase $\mathrm{P}$, hyaluronidase (Boehringer, Mannheim, Germany) and protease E Type XIV from Streptomyces griseus (Sigma, Deisenhofen, Germany) for $45 \mathrm{~min}$ in a $37^{\circ} \mathrm{C}$ shaking water bath to gain single cells (16). Lymphocytes derived from heparinized blood samples were separated in equal amounts of Lymphoprep (Nycomed, Oslo, Norway) using density gradient centrifugation (20 min, $2000 \mathrm{U} / \mathrm{min}, 20^{\circ} \mathrm{C}$ ). Viability and cell count were investigated using trypane blue staining.

Incubation with nitrosamines. Cell aliquots $\left(5 \times 10^{4}\right)$ of the two cell types were incubated for $60 \mathrm{~min}$ with NNN (10 mM, CAS no. 53759-22-0; Merck, Darmstadt, Germany), NNK (10 mM, CAS no. 64091-91-4; Merck) and NDEA (50 mM, CAS. no. 55-18-5, Merck). Dimethyl sulfoxide (DMSO, $166 \mathrm{mM}$; Merck), a solvent of the nitrosamines, served as a negative control. NDEA, as an exemplary representative of the nitrosamines, was used to induce damage prior to DNA repair. After
NDEA was washed from the cells using Joklik medium and centrifugation $\left(24^{\circ} \mathrm{C}, 400 \mathrm{U} / \mathrm{min}, 5 \mathrm{~min}\right)$, aliquots were resuspended in Joklik medium and underwent a DNA repair period of 15 and $30 \mathrm{~min}$ in a shaking water bath at $37^{\circ} \mathrm{C}$. Epithelial cells were suspended in Joklik medium, whereas lymphocytes were maintained in PBS (12).

Comet assay. The performance of the comet assay for the two cell types was mainly based on the protocol of Singh et al (17). Special slides were designed for the comet assay with a frosting of $5 \mathrm{~mm}$ along the long edges $(76 \times 26 \mathrm{~mm}$, Langenbrinck, Emmendingen, Germany), prepared with $85 \mu 1$ of $0.5 \%$ normal melting agarose (Biozym, Hameln, Germany). Following incubation and repair periods, respectively, cell viability was again examined using trypan blue staining. Having obtained viabilities between 90 and $100 \%$, the remaining aliquots were suspended with $75 \mu 1$ of $0.7 \%$ low melting agarose (Biozym) and applied to the prepared slides. Alkaline lysis (10 ml DMSO, $1 \mathrm{ml}$ Triton- $\mathrm{X}^{\circledR}$ and $89 \mathrm{ml}$ alkaline lysis buffer) followed for $1 \mathrm{~h}$. The slides were dried and placed into a horizontal gel electrophoresis chamber (Renner, Dannstadt, Germany), and covered with alkaline buffer solution containing $\mathrm{NaOH}(10 \mathrm{mM})$ and $\mathrm{Na}_{2}$ EDTA $(200 \mathrm{mM})$ with $\mathrm{pH}$ 13.2. Following a 20 min DNA unwinding period, the electrophoresis was started with $25 \mathrm{~V}$ and $300 \mathrm{~mA}$ for $20 \mathrm{~min}$. Following neutralization (0.4 M Tris, pH 7.5, Merck), the cells were stained with $85 \mu \mathrm{l}$ ethidium bromide $(20 \mu \mathrm{g} / \mathrm{ml}$, Sigma). The slides were covered with cover slips and stored for less than three days in humidified boxes at $5^{\circ} \mathrm{C}$.

Digital analysis. The cells were investigated using a DMLB microscope (Leica, Heerbrugg, Switzerland) with an adapted CCD camera (Cohu Inc., San Diego, CA, USA). A total of 40 representative cells were investigated per slide, using two slides for each aliquot tested. For data analysis the median of each subject was used. Cells were counted and analyzed from different spots on the slide to account for variability of the signals. The comets were measured using an image analysis system (Comet $++^{\mathrm{TM}}$, Kinetic Imaging, Liverpool, UK). Comet analysis was performed blinded by one examiner to reduce observer-based divergence. To quantify DNA damage, the Olive Tail Moment (OTM: median DNA migration distance $\mathrm{x}$ relative amount of DNA in the tail of the comet) was used (18). DNA repair was calculated by comparing the initial damage in each subject in relation to the damage left after 15 and $30 \mathrm{~min}$ of repair time.

Statistical analysis. Statistical analysis was performed using SPSS $16.0^{\mathrm{TM}}$. The OTM values of the patients in the two groups were compared (Mann-Whitney U test) as well as tail moments within each group (Wilcoxon test). General acceptance of the level of significance was $\mathrm{p} \leq 0.05$. Bonferroni correction was used where necessary. Standard box-plots (lower, median and upper quartile) were used to show the results.

\section{Results}

The Comet assay was confirmed as being a sensitive method to quantify DNA damage and DRC. DRC was measured after 15 and $30 \mathrm{~min}$ (DRC15 and DRC30). The OTM 
Table I. Characteristics of male control patients.

\begin{tabular}{|c|c|c|c|c|c|c|c|}
\hline No. & Age & BMI & Diagnosis & $\mathrm{Cig} / \mathrm{d}$ & Py & Alcohol /d (g) & $\begin{array}{l}\text { Occupational } \\
\text { hazards }\end{array}$ \\
\hline 1 & 50 & 27 & Acute tonsillitis & 10 & 30 & 100 & \\
\hline 2 & 48 & 22 & Sleep apnea & 30 & 23 & 64 & \\
\hline 3 & 40 & 24 & Chronic tonsillitis & 15 & 20 & 10 & \\
\hline 4 & 47 & 27 & Acute tonsillitis & 15 & 15 & 25 & \\
\hline 5 & 50 & 22 & Chronic tonsillitis & 20 & 20 & 20 & \\
\hline 6 & 42 & 29 & Sleep apnea & 40 & 50 & 10 & \\
\hline 7 & 46 & 28 & Sleep apnea & 50 & 36 & 125 & $\begin{array}{l}\text { Paints, lubricants, } \\
\text { varnish }\end{array}$ \\
\hline 8 & 54 & 22 & Chronic tonsillitis & 25 & 38 & 25 & Metal dust \\
\hline 9 & 40 & 25 & Chronic tonsillitis & 5 & 3 & 25 & \\
\hline 10 & 42 & 27 & Chronic tonsillitis & 20 & 25 & 72 & Chemicals \\
\hline 11 & 52 & 30 & Chronic tonsillitis & 20 & 10 & 175 & \\
\hline 12 & 34 & 22 & Chronic tonsillitis & 2 & 1 & 50 & Paints \\
\hline 13 & 56 & 22 & Chronic tonsillitis & 10 & 10 & 20 & \\
\hline 14 & 40 & 22 & Chronic tonsillitis & 5 & 2 & 37 & \\
\hline 15 & 54 & 30 & Chronic tonsillitis & 20 & 80 & 10 & Wood dust \\
\hline 16 & 42 & 28 & Chronic tonsillitis & 60 & 50 & 20 & \\
\hline 17 & 54 & 21 & Chronic tonsillitis & 20 & 20 & 15 & \\
\hline 18 & 51 & 33 & Chronic tonsillitis & 15 & 16 & 45 & Paints \\
\hline 19 & 48 & 31 & Chronic tonsillitis & 10 & 24 & 10 & \\
\hline 20 & 54 & 27 & Sleep apnea & 20 & 40 & 125 & Metal dust \\
\hline 21 & 50 & 27 & Sleep apnea & 40 & 20 & 290 & \\
\hline 22 & 45 & 28 & Sleep apnea & 30 & 15 & 25 & \\
\hline 23 & 49 & 29 & Sleep apnea & 5 & 8 & 20 & \\
\hline 24 & 43 & 25 & Sleep apnea & 12 & 15 & 40 & \\
\hline 25 & 53 & 19 & Chronic tonsillitis & 10 & 23 & 30 & \\
\hline 26 & 57 & 28 & Sleep apnea & 5 & 15 & 50 & \\
\hline 27 & 52 & 22 & Acute tonsillitis & 12 & 15 & 30 & \\
\hline 28 & 54 & 20 & Acute tonsillitis & 20 & 34 & 175 & \\
\hline 29 & 53 & 26 & Chronic tonsillitis & 5 & 7 & 60 & Wood dust, glue \\
\hline 30 & 46 & 25 & Chronic tonsillitis & 12 & 20 & 65 & \\
\hline 31 & 36 & 25 & Acute tonsillitis & 30 & 21 & 4 & Solvents \\
\hline 32 & 51 & 24 & Chronic tonsillitis & 10 & 15 & 15 & \\
\hline 33 & 44 & 31 & Sleep apnea & 20 & 13 & 30 & \\
\hline 34 & 44 & 28 & Sleep apnea & 15 & 18 & 40 & \\
\hline 35 & 50 & 31 & Acute tonsillitis & 10 & 12 & 25 & \\
\hline 36 & 51 & 24 & Sleep apnea & 20 & 35 & 12,5 & \\
\hline 37 & 57 & 28 & Chronic tonsillitis & 2 & 3 & 69 & Chalk dust \\
\hline 38 & 53 & 27 & Chronic tonsillitis & 20 & 18 & 120 & \\
\hline 39 & 61 & 27 & Sleep apnea & 30 & 40 & 30 & \\
\hline 40 & 45 & 27 & Sleep apnea & 20 & 5 & 25 & \\
\hline 41 & 47 & 32 & Sleep apnea & 25 & 26 & 50 & \\
\hline 42 & 43 & 23 & Chronic tonsillitis & 20 & 18 & 10 & \\
\hline 43 & 61 & 33 & Papilloma & 60 & 80 & 100 & Chemicals \\
\hline 44 & 63 & 28 & Chronic tonsillitis & 25 & 50 & 45 & \\
\hline 45 & 63 & 27 & Chronic tonsillitis & 40 & 60 & 50 & Wood dust \\
\hline 46 & 61 & 27 & Chronic tonsillitis & 25 & 53 & 250 & \\
\hline 47 & 61 & 31 & Sleep apnea & 50 & 27 & 66 & Paints \\
\hline 48 & 60 & 26 & Sleep apnea & 20 & 40 & 40 & \\
\hline 49 & 61 & 28 & Sleep apnea & 30 & 25 & 50 & \\
\hline 50 & 62 & 30 & Chronic tonsillitis & 15 & 30 & 25 & \\
\hline
\end{tabular}

BMI, body mass index; cig/d, cigarettes per day; py, pack years; alcohol/d (g), alcohol per day in grams. 
Table II. Characteristics of male SCC patients.

\begin{tabular}{|c|c|c|c|c|c|c|c|c|c|}
\hline No. & Age & BMI & Diagnosis & TNM & Grading & $\mathrm{Cig} / \mathrm{d}$ & py & $\begin{array}{l}\text { Alcohol/d } \\
(\mathrm{g})\end{array}$ & $\begin{array}{l}\text { Occupational } \\
\text { hazards }\end{array}$ \\
\hline 1 & 50 & 25 & Oropharynx carcinoma & pT4 pN3 cM0 & G3 & 50 & 75 & 240 & \\
\hline 2 & 50 & 32 & Oropharynx carcinoma & pT2 pN3 cM0 & G2 & 50 & 120 & 900 & \\
\hline 3 & 40 & 22 & Oropharynx carcinoma & pT3 pN2a cMx & G3 & 20 & 13 & 175 & \\
\hline 4 & 47 & 24 & Oropharynx carcinoma & pT2 pN2b cM0 & $\mathrm{G} 2$ & 25 & 40 & 100 & \\
\hline 5 & 53 & 24 & Oropharynx carcinoma & pT2 pT1 сM0 & G3 & 30 & 50 & 125 & Kerosene \\
\hline 6 & 46 & 28 & Oropharynx carcinoma & pT1 pN1 cM0 & G3 & 40 & 45 & 50 & Wood dust \\
\hline 7 & 48 & 23 & Uvula carcinoma & pT3 pN2b cM0 & G3 & 20 & 35 & 100 & \\
\hline 8 & 57 & 25 & Oropharynx carcinoma & pT4 pN0 cM0 & G3 & 35 & 20 & 205 & Polyvinylchloride \\
\hline 9 & 44 & 19 & Base of tongue carcinoma & $\mathrm{cT} 4 \mathrm{cN} 0 \mathrm{cM} 0$ & G1 & 100 & 125 & 200 & \\
\hline 10 & 47 & 23 & Oropharynx carcinoma & pT3 pN1 cM0 & G3 & 20 & 30 & 150 & \\
\hline 11 & 48 & 31 & Tonsillar carcinoma & pT2 pN3 cM0 & $\mathrm{G} 2$ & 30 & 48 & 300 & Bitumen \\
\hline 12 & 35 & 22 & Oropharynx carcinoma & $\mathrm{cT} 4 \mathrm{cN} 2 \mathrm{a} \mathrm{cMx}$ & G1 & 50 & 40 & 250 & \\
\hline 13 & 56 & 19 & Oropharynx carcinoma & pT3 cN2c cM0 & $\mathrm{G} 2$ & 60 & 60 & 220 & Metal dust \\
\hline 14 & 44 & 20 & Oropharynx carcinoma & pT4 cN2a cM0 & G3 & 10 & 5 & 10 & \\
\hline 15 & 56 & 27 & Oropharynx carcinoma & pT4 cN2c cM0 & G3 & 30 & 25 & 100 & \\
\hline 16 & 47 & 19 & Base of tongue carcinoma & pT4 pN1 cM0 & G3 & 20 & 20 & 900 & \\
\hline 17 & 56 & 23 & Tonsillar carcinoma & pT2 pN3 cM0 & G3 & 20 & 80 & 60 & Polyvinylchloride \\
\hline 18 & 54 & 19 & Oropharynx carcinoma & pT3 pN2b cM0 & $\mathrm{G} 2$ & 12 & 20 & 160 & Chemicals \\
\hline 19 & 50 & 27 & Base of tongue carcinoma & pT1 pN1 cM0 & G1 & 20 & 34 & 123 & \\
\hline 20 & 54 & 23 & Tonsillar carcinoma & pT2 pN2b cM0 & $\mathrm{G} 2$ & 30 & 55 & 200 & Oils \\
\hline 21 & 52 & 24 & Tonsillar carcinoma & pt1 pN2b cM0 & G3 & 30 & 40 & 144 & \\
\hline 22 & 46 & 22 & Vallecula carcinoma & pT2 pN0 cM0 & G3 & 20 & 63 & 375 & Paints \\
\hline 23 & 50 & 29 & Oropharynx carcinoma & pT2 Pn0 cMx & $\mathrm{G} 2$ & 25 & 23 & 100 & \\
\hline 24 & 43 & 24 & Tonsillar carcinoma & pT3 pN1 cM0 & $\mathrm{G} 2$ & 25 & 15 & 205 & \\
\hline 25 & 55 & 25 & Oropharynx carcinoma & pT3 pN1 cM0 & G3 & 4 & 5 & 50 & \\
\hline 26 & 56 & 25 & Tonsillar carcinoma & pT3 pN2b cM0 & G3 & 30 & 72 & 63 & Solvents \\
\hline 27 & 52 & 32 & Tonsillar carcinoma & pT2 pN2b cM0 & G2 & 30 & 25 & 8 & \\
\hline 28 & 55 & 22 & Oropharynx carcinoma & $\mathrm{pT} 2 \mathrm{pN} 1 \mathrm{cMx}$ & G3 & 40 & 60 & 40 & \\
\hline 29 & 53 & 18 & Oropharynx carcinoma & pT4 pN3 cM0 & G3 & 10 & 8 & 30 & \\
\hline 30 & 46 & 25 & Oropharynx carcinoma & pT1 pN3 cM0 & G1 & 15 & 12 & 300 & \\
\hline 31 & 42 & 24 & Oropharynx carcinoma & pT1 pN2b cM0 & G1 & 20 & 20 & 1000 & \\
\hline 32 & 51 & 24 & Tonsillar carcinoma & pT2 pN1 cM0 & G3 & 20 & 25 & 400 & \\
\hline 33 & 47 & 26 & Uvula carcinoma & pT3 pN1 cM0 & G1 & 30 & 15 & 90 & \\
\hline 34 & 42 & 27 & Vallecula carcinoma & pT2 pN0 cM0 & $\mathrm{G} 2$ & 15 & 15 & 100 & \\
\hline 35 & 54 & 21 & Oropharynx carcinoma & pT4 pN2c cM0 & G3 & 50 & 80 & 100 & \\
\hline 36 & 49 & 20 & Oropharynx carcinoma & pT1 pN0 cM0 & G1 & 20 & 30 & 125 & Metal dust \\
\hline 37 & 55 & 24 & Tonsillar carcinoma & pT3 pN2b cM0 & G2 & 35 & 60 & 80 & \\
\hline 38 & 53 & 27 & Oropharynx carcinoma & pT4 pN2a cM0 & G2 & 20 & 20 & 80 & \\
\hline 39 & 61 & 29 & Uvula carcinoma & pT2 pN0 cM0 & G2 & 40 & 60 & 100 & Paints \\
\hline 40 & 42 & 21 & Tonsillar carcinoma & pZ3 pN2a cM0 & $\mathrm{G} 2$ & 40 & 20 & 100 & \\
\hline 41 & 67 & 25 & Oropharynx carcinoma & pT1 pN1 cMx & G3 & 25 & 35 & 132 & Chemicals \\
\hline 42 & 43 & 19 & Oropharynx carcinoma & pT2 pN0 cM0 & G3 & 20 & 27 & 250 & Cement dust \\
\hline 43 & 62 & 20 & Oropharynx carcinoma & pT3 pN2a cM0 & G1 & 15 & 23 & 60 & \\
\hline 44 & 62 & 31 & Oropharynx carcinoma & pT1 pN2a cM1 & G3 & 20 & 10 & 55 & Paints \\
\hline 45 & 62 & 20 & Vallecula carcinoma & pT1 pN1 cM1 & G3 & 5 & 12 & 35 & \\
\hline 46 & 61 & 27 & Tonsillar carcinoma & $\mathrm{cT} 4 \mathrm{cN} 3 \mathrm{cM} 1$ & G3 & 20 & 23 & 100 & \\
\hline 47 & 62 & 22 & Base of tongue carcinoma & PT2 cN2c cM0 & G2 & 12 & 13 & 50 & \\
\hline 48 & 60 & 25 & Base of tongue carcinoma & pT3 pN2b cM0 & $\mathrm{G} 2$ & 30 & 40 & 20 & \\
\hline 49 & 60 & 29 & Oropharynx carcinoma & pT4 pN2b cM0 & G2 & 20 & 10 & 25 & Asbestos \\
\hline 50 & 62 & 25 & Base of tongue carcinoma & pT2 pN2b cM0 & G1 & 25 & 30 & 40 & \\
\hline
\end{tabular}

BMI, body mass index; cig/d, cigarettes per day; py, pack years; alcohol/d (g), alcohol per day in grams . 

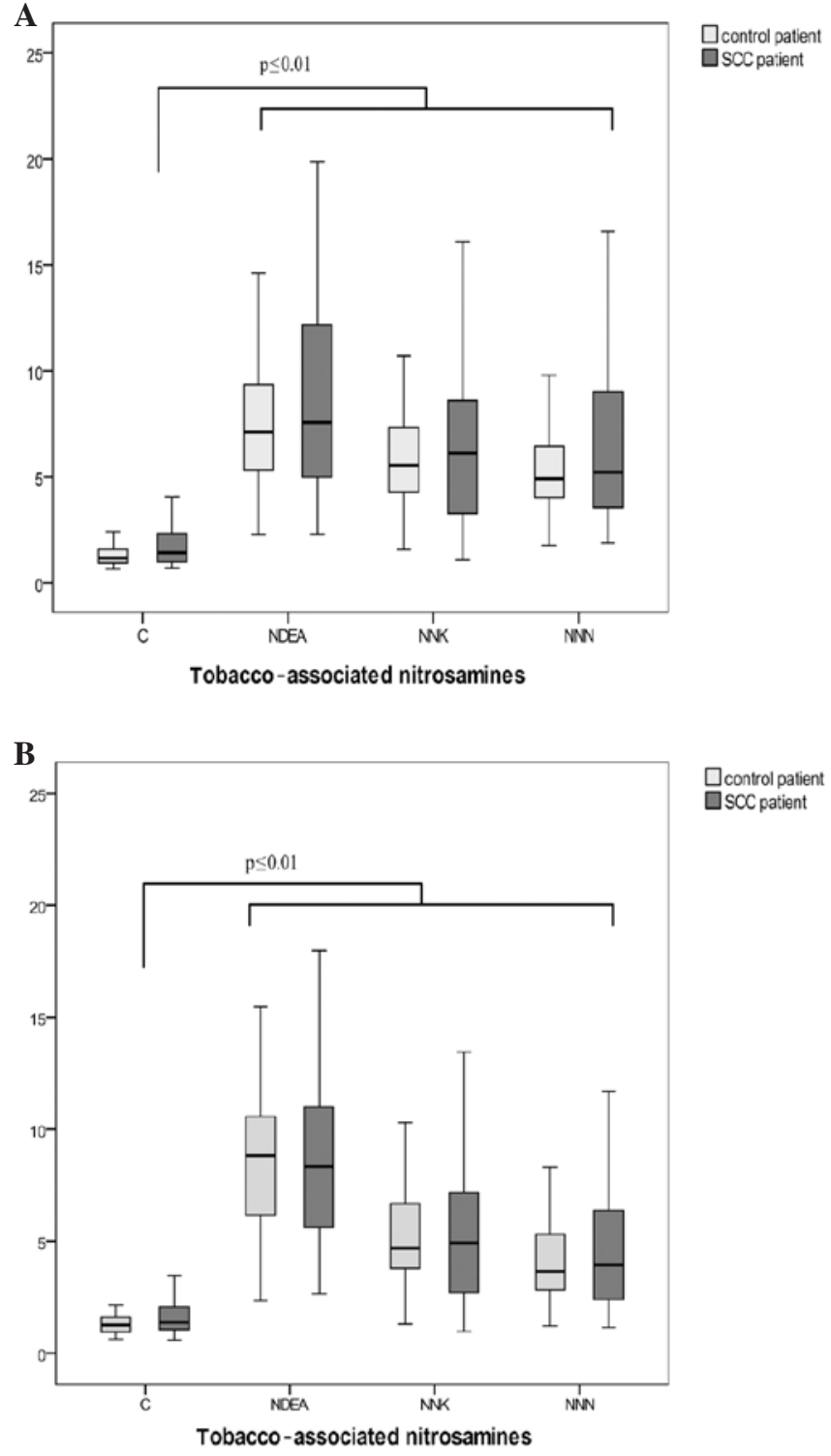

Figure 1. Results of genotoxicity tests in (A) human peripheral lymphocytes and (B) human oropharyngeal mucosa cells after incubation with dimethyl sulfoxide (control/C) as a negative control and the nitrosamines NNN, NNK and NDEA. (A and B) Box plots show the lowest and highest values of OTM as well as the 1st and 3rd quartile and the median. Values are provided for patients without carcinoma (control patients) and the SCC patients.

values provided are medians. History data and diagnoses of the patients are shown in Tables I (controls) and II (SCC patients).

DNA damage in lymphocytes of patients without carcinoma and patients with oropharyngeal carcinoma following incubation with nitrosamines is shown in Fig. 1A. While the solvent DMSO as a negative control did not induce any damage in lymphocyte DNA in tumor and control patients (OTM 1.0 vs. 1.2), significant DNA damage was found following incubation with NDEA (OTM 7.3), NNK (OTM 5.8) and NNN (OTM 5.1) in controls. Only OTMs $>2$ are considered to reflect relevant DNA damage (16). DNA fragmentation in the SCC group was comparable with OTMs 7.4, 6.0 and 5.2 following incubation with NNN ( $\mathrm{p}=0.58), \mathrm{NNK}(\mathrm{p}=0.48)$ and NDEA $(p=0.67)$, respectively.


Figure 2. (A) Mean DRC measured in lymphocytes after incubation with NDEA and 15 and 30 min repair intervals. Values are provided for patients without carcinoma (control patients) and the SCC patients. (B) Mean percentage of DNA repair capacities measured in oropharyngeal mucosa cells after incubation with NDEA and 15 and 30 min repair intervals. Values are provided for patients without carcinoma (control patients) and the SCC patients.

Fig. 1B shows genotoxicity levels of oropharyngeal epithelial cells following incubation with DMSO (negative control) and the nitrosamines NNN, NNK and NDEA. In the control group, OTMs of 1.3 (DMSO), 8.3 (NDEA), 4.7 (NNK) and 3.9 (NNN) were determined. DNA derived from oropharyngeal epithelial cells of cancer patients yielded OTMs of 7.9 (NDEA), 4.8 (NNK) and 4.0 (NNN) following nitrosamine incubation with an OTM of the negative control of 1.3 (DMSO). No significant differences were observed in DNA damage between tumor patients and patients without malignancy $[\mathrm{p}=0.55$ (NDEA), $\mathrm{p}=0.95(\mathrm{NNK})$ and $\mathrm{p}=0.67(\mathrm{NNN})]$.

DNA repair in lymphocytes following NDEA incubation is shown in Fig. 2A. For the controls, DRC15 was $26.8 \%$ and DRC30 was $37.1 \%$. The mean DRC15 and DRC30 of cancer patients was 23.6 and $40.5 \%$, respectively. Differences in lymphocyte DNA repair were not observed between the two groups of donors, with $\mathrm{p}=0.46(\mathrm{DRC} 15)$ and $\mathrm{p}=0.62$ (DRC30).

However, significant differences were found for the DNA repair capacity between cases and controls for DRC30. The results are shown in Fig. 2B. Following DNA damage caused by NDEA, controls reached DRC levels of 36.2\% (DRC15) and $46 \%$ (DRC30). Cells of SCC patients yielded a DRC15 of $23 \%$ and a DRC30 of $17.1 \%$. OTM values following damage and 15-min repair were 7.3 and following a 30-min repair period 7.86, which demonstrates the arrest of repair action in the cells of carcinoma patients after $20 \%$ of repaired damage. Statistical evaluation of DNA repair of the two groups resulted in $\mathrm{p}=0.09$ (DRC15) and $\mathrm{p} \leq 0.01$ (DRC30). 


\section{Discussion}

Besides laryngeal cancer, oropharyngeal SCC is the most common alcohol- and tobacco-induced head and neck malignancy. Over $90 \%$ of all cases are histopathologically classified as SCC (1). In 100 cancer and non-cancer patients, we investigated mutagen sensitivity following exposure to tobacco-associated nitrosamines. Consecutively to NDEAinduced damage, we determined DRC after 15 and $30 \mathrm{~min}$. We applied the alkaline comet assay as an established sensitive method for the detection of DNA damage and repair and as an accepted biomarker model (19). The comet assay is widely used in ecogenotoxicology studies and as a predictor for tumor therapies, such as radiotherapy (20). While it remains the subject of controversy, OTM is the most informative measure in the comet assay (21).

Oropharyngeal epithelium is the first target for ingested and inhaled carcinogens and therefore employed as test material in this study. Lymphocytes, which have been used in numerous other previous studies evaluating DRC with the comet assay, were also utilized $(13,14,22,23)$.

In the present study, no significant differences in lymphocytic or mucosal mutagen sensitivity were determined between cancer and non-cancer patients. Wu et al found mutagen sensitivity to be a marker for the identification of an increased risk of developing premalignant lesions in the head and neck, using lymphocytes exposed to benzo[a]pyrene diol epoxide (BPDE) and bleomycin (24). In our study, following incubation of the mucosal cells of SCC patients and controls with BPDE, OTMs of the initial DNA damage did not significantly differ. Increased lymphocyte sensitivity to bleomycin has also been observed in lung cancer patients and proven to be a potential biomarker for second primary tumor development in the upper aerodigestive tract $(14,25)$. Further support for the impact of mutagen sensitivity on the carcinogenic process results from the findings by Schantz et al. These authors correlated mutagen sensitivity to chromosome 3 p losses known to play a key role in the initiation phase of head and neck cancer development (26).

Following incubation of lymphocytes with NDEA, increased mutagen sensitivity was determined in patients suffering from nasopharyngeal carcinoma, whereas no increased sensitivity was observed following exposure to sodium dichromate and nickel sulphate (27). This may be due to different patient groups and diversity of cells compared to the present study. Investigations on mucosa of head and neck cancer patients indicated increased levels of mutagen sensitivity for SCC patients (16). Studies using the comet assay revealed significantly higher DNA damage in Barrett's epithelium compared with healthy squamous epithelium of the oesophagus (28). However, although we compared patients with SCC of the oropharynx to non-tumor patients in an extended case-control study, including matching of gender, age, tobacco and alcohol consumption, we did not find any significant differences in mutagen sensitivity using lymphocytes or mucosa cells. The results demonstrate the importance of matched groups. Moreover, testing of mutagen sensitivity appears to depend on the test system and mutagen used, as well as on the population and cell type to be investigated.

Notably, mutagen sensitivity did not appear to be a risk factor for the development of malignant lesions in our test system.
Accordingly, DNA repair was investigated as another possible endogenous marker in head and neck carcinogenesis. The comet assay has been adapted for the detection of DNA repair in lymphocytes $(12,29,30)$. Certain investigations reported differences in DNA repair following stimulation, dependent on the type of DNA damage induced $(31,32)$. Lymphocytes in our study were not stimulated prior to testing, due to recommendations by Mayer et al after the determination of a lack of differences in lymphocytic DRC following PHA-stimulation and $\gamma$-irradiation (33). Consequently, the group considered unstimulated mucosa cells from fresh biopsy samples. The use of mucosa cells has previously been described with only minor changes to original lymphocyte protocol (12) and has been published earlier $(15,29)$.

In the present study, lymphocyte DRC15 $(\mathrm{p}=0.455)$ and DRC30 ( $\mathrm{p}=0.619)$ did not differ between cancer patients and patients without malignancy following incubation with NDEA. However, in mucosal cells, DRC15 and DRC30 levels were found to be lower in patients with oropharyngeal tumors vs. controls, although the significance was only observed in DRC30 (Fig. 2B).

The present study demonstrates that DRC of the upper aerodigestive tract target cells is a potential endogenous factor for head and neck cancer susceptibility. However, our data provide evidence that there is no difference in DNA fragility to cigarette smoke-related carcinogens. By contrast, overall DRC appears to be rapidly saturated in HNSCC patients, whereas patients without malignancy are able to continuously increase the proportion of repaired DNA damage with time. The findings of other groups support the role of hereditary reduced DNA repair capacities as risk factors for head and neck cancer $(13,34)$. Additionally, gene polymorphisms in proteins, such as XPD and XRCC1 exert a major role in DNA repair, and thus affect head and neck carcinogenesis $(30,35,36)$. Due to the diverse findings in the cell systems tested in this study, we recommend the use of target tissue cells to investigate DRC in upper aerodigestive tract carcinogenesis. Further studies are likely to focus on the identification of specific chromosomal and genetic alterations in mucosal cells of the upper aerodigestive tract. Previously, a higher sensitivity to tobaccorelated carcinogens was determined in chromosomes 3,5 and 8 in oropharyngeal epithelia of head and neck tumor patients compared to controls $(37,38)$. Further investigation of such data would provide more detailed information on cancer risks and may be the basis for new preventive and therapeutic treatments in head and neck carcinogenesis.

\section{References}

1. Hunter KD, Parkinson EK and Harrison PR: Profiling early head and neck cancer. Nat.Rev.Cancer 5: 127-135, 2005.

2. Warnakulasuriya S, Sutherland G and Scully C: Tobacco, oral cancer, and treatment of dependence. Oral Oncol 41: 244-260, 2005.

3. Cloos J, Nieuwenhuis EJ, Boomsma DI, Kuik DJ, van der Sterre ML, Arwert F, Snow GB and Braakhuis BJ: Inherited susceptibility to bleomycin-induced chromatid breaks in cultured peripheral blood lymphocytes. J Natl Cancer Inst 91: 1125-1130, 1999.

4. IARC: Iarc Monographs on the Evaluation of the Carcinogenic Risk of Chemicals to Humans: N'-Nitrosonornicotine (Nnn). IARC, 2007.

5. Hecht SS: DNA adduct formation from tobacco-specific N-nitrosamines. Mutat Res 424: 127-142, 1999. 
6. Koppang N, Rivenson A, Dahle HK and Hoffmann D: A study of tobacco carcinogenesis, Liii: carcinogenicity of N'-nitrosonornicotine (Nnn) and 4-(methylnitrosamino)-1(3-pyridyl)-1-butanone (Nnk) in mink (Mustela Vison). Cancer Lett 111: 167-171, 1997.

7. IARC: Iarc Monographs on the Evaluation of the Carcinogenic Risk of Chemicals to Humans: N-Nitrosodiethylamine (Ndea) IARC, 2000

8. Weitberg $\mathrm{AB}$ and Corvese $\mathrm{D}$ : Oxygen radicals potentiate the genetic toxicity of tobacco-specific nitrosamines. Clin Genet 43: 88-91, 1993.

9. Compagni A and Christofori G: Recent advances in research on multistage tumorigenesis. Br J Cancer 83: 1-5, 2000.

10. Hartwell LH and Weinert TA: Checkpoints: controls that ensure the order of cell cycle events. Science 246: 629-634, 1989.

11. Sancar A: Mechanisms of DNA excision repair. Science 266: 1954-1956, 1994.

12. Schmezer P, Rajaee-Behbahani N, Risch A, Thiel S, Rittgen W, Drings P, Dienemann H, Kayser KW, Schulz V and Bartsch H: Rapid screening assay for mutagen sensitivity and DNA repair capacity in human peripheral blood lymphocytes. Mutagenesis 16: 25-30, 2001.

13. Cheng L, Eicher SA, Guo Z, Hong WK, Spitz MR and Wei Q: Reduced DNA repair capacity in head and neck cancer patients. Cancer Epidemiol. Biomarkers Prev 7: 465-468, 1998.

14. Rajaee-Behbahani N, Schmezer P, Risch A, Rittgen W, Kayser KW, Dienemann H, Schulz V, Drings P, Thiel S and Bartsch H: Altered DNA repair capacity and bleomycin sensitivity as risk markers for non-small cell lung cancer. Int J Cancer 95: 86-91, 2001.

15. Kleinsasser NH, Wallner BC, Kastenbauer ER, Muenzenrieder RK and Harreus UA: Comparing the genotoxic sensitivities of human peripheral blood lymphocytes and mucosa cells of the upper aerodigestive tract using the comet assay. Mutat Res 467: 21-30, 2000.

16. Harreus U, Schmezer P, Kuchenmeister F and Maier H: Genotoxic effect on human mucous membrane biopsies of the upper aerodigestive tract. Laryngorhinootologie 78: 176-181, 1999.

17. Singh NP, McCoy MT, Tice RR and Schneider EL: A simple technique for quantitation of low levels of DNA damage in individual cells. Exp Cell Res 175: 184-191, 1988.

18. Olive PL, Durand RE, Le RJ, Olivotto IA and Jackson SM: Gel electrophoresis of individual cells to quantify hypoxic fraction in human breast cancers. Cancer Res 53: 733-736, 1993

19. Glei M, Habermann N, Osswald K, Seidel C, Persin C, Jahreis G and Pool-Zobel BL: Assessment of DNA damage and its modulation by dietary and genetic factors in smokers using the comet assay: a biomarker model. Biomarkers 10: 203-217, 2005.

20. McKeown SR, Robson T, Price ME, Ho ET, Hirst DG and McKelvey-Martin VJ: Potential use of the alkaline comet assay as a predictor of bladder tumour response to radiation. $\mathrm{Br} \mathbf{J}$ Cancer 89: 2264-2270, 2003.

21. Burlinson B, Tice RR, Speit G, Agurell E, Brendler-Schwaab SY, Collins AR, Escobar P, Honma M, Kumaravel TS, Nakajima M, Sasaki YF, Thybaud V, Uno Y, Vasquez M and Hartmann A: Fourth international workgroup on genotoxicity testing: Results of the in vivo comet assay workgroup. Mutat Res 627: 31-35, 2007.

22. Sasiadek M, Schlade-Bartusiak K, Zych M, Noga L and Czemarmazowicz H: Opposite responses in two DNA repair capacity tests in lymphocytes of head and neck cancer patients. J Appl Genet 43: 525-534, 2002.
23. Palyvoda O, Mukalov I, Polanska J, Wygoda A, Drobot L, Widel $\mathrm{M}$ and Rzeszowska-Wolny J: Radiation-induced DNA damage and its repair in lymphocytes of patients with head and neck cancer and healthy donors. Anticancer Res 22: 1721-1725, 2002.

24. Wu X, Lippman SM, Lee JJ, Zhu Y, Wei QV, Thomas M, Hong WK and Spitz MR: Chromosome instability in lymphocytes: A potential indicator of predisposition to oral premalignant lesions. Cancer Res 62: 2813-2818, 2002.

25. Cloos J, Leemans CR, van der Sterre ML, Kuik DJ, Snow GB and Braakhuis BJ: Mutagen sensitivity as a biomarker for second primary tumors after head and neck squamous cell carcinoma. Cancer Epidemiol Biomarkers Prev 9: 713-717, 2000.

26. Schantz SP, Huang Q, Shah K, Murty VV, Hsu TC, Yu G, Andersen PE, Huvos AG and Chaganti RS: Mutagen sensitivity and environmental exposures as contributing causes of chromosome $3 p$ losses in head and neck cancers. Carcinogenesis 21: 1239-1246, 2000.

27. Kleinsasser NH, Wagner C, Wallner BC, Harreus UA and Kastenbauer ER: Mutagen sensitivity of nasopharyngeal cancer patients. Mutat Res 491: 151-161, 2001.

28. Olliver JR, Hardie LJ, Dexter S, Chalmers D and Wild CP: DNA damage levels are raised in Barrett's oesophageal mucosa relative to the squamous epithelium of the oesophagus. Biomarkers 8 : 509-521, 2003.

29. Harreus UA, Wallner BC, Kastenbauer ER and Kleinsasser NH: DNA repair if mucous membrane cells and lymphocytes with the comet assay. Laryngorhinootologie 80: 23-26, 2001.

30. Spitz MR, Wei Q, Dong Q, Amos CI and Wu X: Genetic susceptibility to lung cancer: the role of DNA damage and repair. Cancer Epidemiol Biomarkers Prev 12: 689-698, 2003.

31. Boerrigter ME and Vijg J: Induction and disappearance of DNA single-strand breaks in human B and T lymphocytes after exposure to ethylnitrosourea. Mutat Res 255: 49-55, 1991.

32. Leroy T, Lison D and Lauwerys R: Preliminary in vitro investigation into the use of alkaline elution assay for the biomonitoring of humans exposed to genotoxic agents. Hum Exp Toxicol 14: 61-68, 1995

33. Mayer C, Popanda O, Zelezny O, von Brevern MC, Bach A, Bartsch $\mathrm{H}$ and Schmezer P: DNA repair capacity after $\gamma$-irradiation and expression profiles of DNA repair genes in resting and proliferating human peripheral blood lymphocytes. DNA Repair (Amst) 1: 237-250, 2002.

34. Schantz SP, Zhang ZF, Spitz MS, Sun M and Hsu TC: Genetic susceptibility to head and neck cancer: Interaction between nutrition and mutagen sensitivity. Laryngoscope 107: 765-781, 1997.

35. Caldecott KW: Xrcc1 and DNA strand break repair. DNA Repair (Amst) 2: 955-969, 2003.

36. Han J, Hankinson SE, Colditz GA and Hunter DJ: Genetic variation in $\mathrm{Xrcc1}$, sun exposure, and risk of skin cancer. Br J Cancer 91: 1604-1609, 2004.

37. Harreus UA, Kleinsasser NH, Zieger S, Wallner B, Reiter M, Schuller $\mathrm{P}$ and Berghaus A: Sensitivity to DNA-damage induction and chromosomal alterations in mucosa cells from patients with and without cancer of the oropharynx detected by a combination of Comet assay and fluorescence in situ hybridization. Mutat Res 563: 131-138, 2004

38. Reiter M, Baumeister P, Zieger S and Harreus U: Chromosomal alterations and mutagen sensitivity in human mucosal cells of the oropharynx and lymphocytes caused by Bpde. Cancer Genomics Proteomics 6: 247-254, 2009. 